\title{
A Review on Human Deaths Associated with Rabies in Nigeria
}

\author{
Otolorin Gbeminiyi Richard $^{1 *}$, Aiyedun Julius Olaniyi ${ }^{4}$, Mshelbwala Philip Paul ${ }^{2}$, Ameh Veronica Odinya $^{1}$, Dzikwi Asabe Adamu ${ }^{1}$, Dipeolu Morenike Atinuke ${ }^{5}$ \\ and Danjuma Friday Audu $^{3}$
}

${ }^{1}$ Department of Veterinary Public Health and Preventive Medicine, Faculty of Veterinary Medicine, Ahmadu Bello University, Zaria Kaduna State, Nigeria.

${ }^{2}$ Department of Veterinary Medicine, Faculty of Veterinary Medicine, Ahmadu Bello University, Zaria Kaduna State, Nigeria

${ }^{3}$ Department of Theriogeniology and production, Faculty of Veterinary Medicine, Ahmadu Bello University, Zaria Kaduna State, Nigeria

${ }^{4}$ Department of Veterinary Public Health and Preventive Medicine, Faculty of Veterinary Medicine, University of ilorin, Kwara State, Nigeria

${ }^{5}$ Department of Veterinary Public Health and Preventive Medicine, College of Veterinary Medicine, Federal University of Agriculture Abeokuta, Ogun State, Nigeria

*Corresponding author: Otolorin GR, Department of Veterinary Public Health and Preventive Medicine, Faculty of Veterinary Medicine, Ahmadu Bello University, Zaria Kaduna State, Nigeria, Tel: +2348065959406; E-mail: drniyiotolorin@yahoo.com

Received date: 12 November 2014; Accepted date: 16 December 2014; Published date: 20 December 2014

Copyright: (c) 2015 Otolorin GR, et al. This is an open-access article distributed under the terms of the Creative Commons Attribution License, which permits unrestricted use, distribution, and reproduction in any medium, provided the original author and source are credited.

\begin{abstract}
Rabies is a viral zoonotic disease that affects all warm blooded mammals, transmitted primarily by bites from rabid dogs. Rabies has the highest case fatality rate of most infectious disease in humans. This research takes a look at a review of human deaths due to rabies across various health care institutions in Nigeria and the situation of rabies in Nigeria. The detection of rabies antigen in the brain tissue of apparently healthy dogs slaughtered for human consumption in some states in Nigeria has given an indication of the endemicity of the disease and the public health risk it poses. Result of human deaths due to rabies obtained from 10 States in Nigeria, gave a total of 78 deaths due to rabies. All of which were not confirmed by laboratory techniques only by clinical presentation. Reported cases of rabies in humans in Nigeria are low; this could be attributed to poor reporting of cases, cultural beliefs, mis-diagnosis of the disease and poor knowledge on the mode of transmission and prevention of the disease. There are increasing numbers of reported cases of dog bites in humans in both rural and urban areas in Nigeria. Published researches in Nigeria have reported deaths in humans due to rabies infection. It is important that the Nigerian government consider rabies control as high priority and hence, a collaborative effort between Veterinarians and human health care professionals on national rabies control program will help in the control of rabies.
\end{abstract}

Keywords: Rabies; Humans; Deaths; Nigeria

\section{Background}

Rabies is a viral zoonotic disease and remains an important public health issue in Nigeria. Majority of human deaths as a result of rabies are due to bites from rabid dogs. The domestic dog (Canis familiaris) plays a pivotal role in rabies transmission [1-4]. In Nigeria and many African countries reports on human death due to rabies infection are low as a result of under-reporting, cultural beliefs, poor or inadequate rabies diagnostic units and poor knowledge on the mode of transmission and prevention of the disease [5]. Under-reporting of human rabies in endemic countries in Africa has led to the disease being neglected by relevant health care facilities and subsequently poor assistance from international community and donor agencies [6]. Routine vaccination of dogs against rabies in Nigeria and most African countries population is low [7]. Rabies was first confirmed in Nigeria by the demonstration of negri bodies in processed brain smear of a rabid dog in the year 1925 [8]. Annual report in the year 1942 by the Veterinary division of Northern Nigeria recorded canine rabies outbreaks from Kano, Kaduna, Borno and Kwara states. Similarly, in 1946 outbreaks were reported from Plateau, Benue and Enugu states. Further reports by the National Veterinary Research Institute (NVRI) Vom, revealed that about 3,555 out of 3,770 animal rabies cases confirmed in Nigeria occurred in dogs during the period 1928 to 1990 [9].
From a survey of cases of human rabies in Nigeria in the year 1981 by the use of questionnaires, review of hospital records and case notes. About 169 cases of laboratory or clinically diagnosed human rabies cases were recorded from 38 health care centres and five state epidemiological units over a 10-year period (1969-1978) [10]. A total of 167 (99\%) were bitten by dogs, one by a cat and one by a monkey in captivity. The study also reported high incidence of human rabies in low socio-economic or illiterate group in rural areas. Hence it can be deduced that poor awareness on the consequences and severity of the disease coupled with inadequate post-exposure anti-rabies treatment in rural areas account for the high incidence of rabies in these areas [10].

Non-bite exposure includes inhalation of aerosolized rabies virus, cornea/organ transplants and contamination of abrasions, open wounds, mucous membranes with rabies antigen laden saliva or with infectious material such as brain tissue from a rabid animal. It is worthy of note that human-to-human transmission of rabies via bites and non-bite exposures by humans infected with rabies could occur theoretically, but there haven't been any documented cases of such $[11,12]$.

Estimated number of human rabies cases and those officially reported do not tally in most instances. This is seen in the entire developing world, but mostly in Africa [6]. Human fatalities associated with rabies infection in humans occur frequently in individuals who lack access to proper health care or have no resources for treatment [13]. Estimated number of human deaths from rabies infection (with 
95\% confidence intervals) as at 2010 in Africa was 23,800 $(21,000-28,000)$ [14]. The incubation period of human rabies ranges between 5 days to several years (usually 2-3 months; rarely exceeding 1 year), depending on the amount of rabies viral antigen in the inoculum, the density of motor endplates at the site of the wound and the proximity of rabies viral antigen entry to the central nervous system $[15,16]$.

During the 2006 census dog population in Nigeria was estimated to be between 2 and 5 million [17]. Reports by authors in different parts of Nigeria have revealed increasing number of dog bite cases in humans [18-28]. A retrospective studies of dog bite cases in Abia State, Nigeria, revealed that $6 \%$ of the offending dogs involved in dog bite cases were suspected to be rabid although no confirmatory diagnosis were made [25] posing serious public health concerns. Dog population in Nigeria seems to be on the increase as recent dog ecological study in Nigeria has established the presence of high density of dogs in some urban areas in the country [26,29-31], with anti-rabies vaccination coverage of dogs falling below $50 \%$ in these areas. These studies have also reported the presence of stray dogs in most of the streets surveyed. As a result of increasing growth of dog and human populations and burden of deaths due to human rabies, the economic costs of rabies control will continue to be enormous in the absence of concerted efforts and appropriate investment for its control [14]. The endemicity of rabies in Nigeria has been established as research carried out in various states across the country have reported the presence of rabies viral antigen in brains of apparently healthy dogs slaughtered for human consumption [27,32-43].

Due to the dominant role domestic dogs play in the anthropophilic transmission of rabies to humans [44], there is need for regular antirabies vaccination of dogs for effective control of urban rabies worldwide [45]. To properly control rabies and eventually eliminate the disease among dog population, there should be annual anti-rabies vaccination and public enlightenment programs/campaigns in order to achieve vaccination coverage of at least $70 \%$. This vaccination coverage should be adequate enough to maintain the required level of herd immunity in the vaccinated population irrespective of dog population turnover rates such as deaths, births, immigration, emigration in the period between campaigns $[46,47]$. An example of the effectiveness of rabies control was seen in Bali an Island in Indonesia where since the introduction of mass dog anti-rabies vaccination as control strategy from late 2010, the numbers of human and animal cases of rabies have decreased drastically: the number of human cases decreased by $72 \%$ between 2010 and 2011 and by $90 \%$ between 2010 and 2012 [14]. This measure can effectively be adopted in Nigeria in order to control the disease.

Poor control of rabies in animals makes it easy for a spill over to the human population. Free roaming/straying of dogs and absence of leash laws are some of the factors encouraging the spread of rabies from dogs to humans in Nigeria [48,49]. Early diagnosis of rabies in dogs and other animals is very important as it forms the basis for postexposure treatment of humans for the prevention of rabies. Prompt and adequate administration of purified cell culture or embryonated egg-based human rabies vaccines after exposure combined with proper wound management and simultaneous treatment with rabies immunoglobulin are the most effective treatment in order to prevent rabies in humans, even after a high-risk exposure [50]. Rabies immunoglobulin, which provides neutralizing antibodies in exposed patients before they can generate their own antibodies after vaccination with human rabies vaccine are limited in supply world- wide [14]. A single dose of human rabies vaccine is approximately three times more expensive than animal rabies vaccines in Nigeria [48]. Exposed humans require five doses of human rabies vaccines for effective post-exposure treatment

Recent reports by Mshelbwala et al. [25] and Otolorin et al. [28] in Abia state Nigeria revealed that some dog bite victims sought traditional methods of treatment which has no scientific bases thereby making the control of rabies in the State difficult. The level of care rendered to dog bite victims has a role to play in the prevention of human rabies [51]. Due to poor laboratory-guided surveillance in Nigeria that aid in the confirmation of rabies cases, it is difficult to take record of geographical location, seasonal influence, prevalence and species affected as it concerns rabies, this is a major factor leading to gross under-reporting of both human and animal rabies [52]. Public awareness is a viable and non-expensive means of rabies prevention and control. When public awareness tools such as sporting and outdoor events, visual arts, mass media and vaccination campaigns are employed good public awareness regarding rabies prevention is made known to the populace [1]. The primary task of animal health care professionals is to control rabies in animals through a well planned sustainable strategy towards rabies control, hence leading to a corresponding reduction in human rabies. In many countries, there is a lack of cooperation between the ministries of agriculture and the ministry of health, leading to an over-all poor implementation of rabies control program. Subsequently dog owners are then left with the primary responsibility of vaccinating their dogs against rabies or preventing their dogs from coming into contact with rabid animals [53].

\section{Dog Meat Processing/Consumption and Public Health Risks to Dog Meat Processors in Nigeria}

Dog trading and consumption of dog meat is a common practice in some parts of Nigeria serving as a source of livelihood for some individuals. In Nigeria stray/free-roaming dogs are easily captured by dog thieves and usually sold off at dog market, most of these dogs are transported from the northern parts of Nigeria where there are large dog markets to the southern parts of the country [54]. The process of commercial dog meat production at every stage is cruel to the animals. Dogs meat processing and consumption is carried out most commonly in the following states in Nigeria namely Kaduna, Cross River, Akwa ibom, Plateau, Taraba Gombe and Ondo States. Dog meat processing for human consumption predisposes the transmission of rabies virus from infected to non-infected dogs, the dog owners and dog meat processors usually through dog bite injuries [27] also where slaughtering and processing of dog meat are done without the right equipment and protective gears there is bound to be a risk of possible transmission of the disease to the handlers [55]. Dog markets have also been implicated as major foci of spread of rabies and other zoonotic diseases in Nigeria and other part of Africa.

From a study conducted at the University of Calabar Teaching Hospital (UCTH) to analyse hospital records of patients diagnosed with rabies between July and October 2012, eight out of the nine rabid patients got infected directly or indirectly through trading in stray dogs for human consumption [40] giving an indication of the high risk dog meat processors are exposed to. Because dog meat in some part of the country is on high demand and local butchers find it difficult to isolate suspected rabies infected animals from the healthy ones control of rabies particularly in the rural areas of the country seems very difficult [56]. 
Page 3 of 6

There is also a risk of transmission of the disease to humans when rabies virus contained in body fluids or nervous tissues of infected animals come in contact with abraided skin or mucus membrane of dog meat processors prior to the cooking of the meat. Source of rabies infection could emanate from the rabies viral antigen contaminated utensils and sales tables used at the slaughter and sales points [57].

Dog meat is consumed for various reasons notably for its medicinal potency as a cure for malaria, as an aphrodisiac, its taste and as protection against attack by evil spirits $[58,59]$. It is worthy of note that in most developing countries, especially in Nigeria, dogs are transported together with goods and humans in the same cabin of the vehicle. This further increases the spread of the virus from dogs to humans. Also, dogs on transit from far distances go through starvation for days making them easily irritable and exhausted. This may lead to fights among the dogs, inflicting wounds from bites on themselves which may easily aid the spread of rabies virus. This is even made worse especially in a situation where dogs with unknown medical history are all caged together in tight boxes [54]. Family pressure makes it difficult for most dog meat processors and handlers to give up the trade, particularly when such individuals possess large family size and need to cater for their needs [57].

The presence of rabies antigen in the brain tissue of dogs slaughtered for human consumption in states in Nigeria indicates that dog meat processors are exposed to rabies infection and hence require adequate public health education on the need to adhere to proper safety measures when handling these dogs and a need for regular yearly anti-rabies vaccination since banning the trade will be very difficult $[39,41]$.

Human consumption of dog meat is not only restricted to Nigeria, this practice has been recorded in many parts of the world, including countries in West-Africa, China, Indonesia, Thailand, Korea, Cambodia, Mexico, Vietnam and in Switzerland. One common belief by dog meat consumers all over the world is that it has medicinal properties and a good taste, making it difficult for the abolition of this practice. In recent times some cultures view dog meat consumption to be an essential part of their meals, while there have been great concerns among animal right groups particularly in developed countries who consider consumption of dog meat to be unacceptable, inappropriate and offensive on both social and religious grounds. Organizations such as the World Society for the Protection of Animals has been increasingly directed against dog meat consumption and inhumane treatment of dogs caged and reared for their meat (Wikipedia, dog meat 2014). Most of the countries that consume dog meat are in Africa and Asia, hence death due to human rabies in these countries are relatively high. This may not be unconnected to risky practices undertaken by dog meat processors and handlers who may be exposed to the rabies virus in the course of their daily activities. The estimate of human deaths in Africa and Asia in the year 2010 using the Probability decision-tree approach was $58,300(35,000-82,000)$ while human death due to rabies in the world was estimated at 61,000 $(37,000-86,000)[14]$.

Dog trading in Nigeria is common among neighbouring countries including Cameroon, Chad and Niger. There have been reports that rabies isolates from dogs in Plateau State, Nigeria were antigenically related to isolates from Cameroon, Chad, Benin Republic and Northern Africa [54]. This indicates the endemicity of the disease within these countries and continuous dog trading predisposes possible transmission of rabies virus among these countries. Recent studies have reported extremely limited availability of post-exposure prophylaxis treatment against rabies in most of sub-Saharan Africa making the control of rabies in this region difficult. Data concerning deaths due to human rabies in countries bordering Nigeria such as Niger, Chad, Cameroon and Benin-republic are limited. In-depth studies show that official reports in some Africa countries may underestimate the incidence of rabies by more than 100-fold, because most deaths occur in communities and are not reported to relevant health care authorities. The 2010 estimate of the human death due to rabies in Africa using the probability decision-tree approach was about 23800 deaths (95\% CI, 21,000-28,000). The challenge with estimating this figures are few available data for validation [14].

\section{Result of Deaths due to Human Rabies Recorded in Health Care Centres Across Nigeria between 1980 to 2014}

Result of human deaths due to rabies gotten from 10 States in Nigeria, gave a total of 78 deaths due to rabies (Table 1). All of which were not confirmed by laboratory techniques only by clinical presentation. It is difficult to carry out Autopsies to determine the cause of death in Nigeria because of religious and cultural concerns. Diagnosis is majorly carried out by clinical presentation coupled with history of exposure to rabies infected animal. This number of human deaths due to rabies gotten from this review is a far cry to the number of human death due to the diseases. As under-reporting and misdiagnosis are major factors that contributes to poor records of the devastating effect of the disease to humans in Nigeria.

\begin{tabular}{|l|l|l|l|l|l|l|l|}
\hline $\mathbf{s} / \mathbf{n}$ & States & Institution & Year under study & $\begin{array}{l}\text { No of suspected } \\
\text { cases of rabies } \\
\text { in patients }\end{array}$ & $\begin{array}{l}\text { No of laboratory } \\
\text { confirmed cases } \\
\text { in dead patients }\end{array}$ & $\begin{array}{l}\text { No of death } \\
\text { recorded } \\
\text { humans }\end{array}$ \\
\hline 1 & Adamawa & $\begin{array}{l}\text { Federal Medical } \\
\text { Centre }\end{array}$ & 2012 & 1 & nil & nil \\
\hline 2 & Bauchi & $\begin{array}{l}\text { Ministry } \\
\text { Agriculturer And } \\
\text { Natural Resources, } \\
\text { Bauchi }\end{array}$ & $1987-2010$ & 5 & nil & 5 & [50] \\
\hline 3 & Cross-river & $\begin{array}{l}\text { University of Calabar } \\
\text { Teaching Hospital, } \\
\text { Calabar }\end{array}$ & July-October & 10 & nil & 10 & [40] \\
\hline
\end{tabular}




\begin{tabular}{|c|c|c|c|c|c|c|c|}
\hline 4 (a) & Edo & $\begin{array}{l}\text { University of Benin } \\
\text { Teaching Hospital, } \\
\text { Benin }\end{array}$ & $\begin{array}{l}\text { January } 1997- \\
\text { December } 2008\end{array}$ & 1 & nil & 1 & [21] \\
\hline $4(\mathrm{~b})$ & Edo & $\begin{array}{ll}\text { Modic } & \text { Medical } \\
\text { Centre } & \end{array}$ & $\begin{array}{l}\text { January 1994- } \\
\text { December } 2005\end{array}$ & 1 & nil & 1 & [61] \\
\hline 5 & Ekiti & $\begin{array}{l}\text { Federal Medical } \\
\text { Centre Ido Ekiti }\end{array}$ & $\begin{array}{l}\text { January 2009- } \\
\text { December } 2011\end{array}$ & 1 & nil & 1 & [62] \\
\hline 6 (a) & Kaduna & $\begin{array}{lr}\text { Kaduna } & \text { State } \\
\text { Ministry } & \text { of } \\
\text { Agriculture, } & \text { Kaduna }\end{array}$ & 1999-2009 & 9 & nil & 9 & [63] \\
\hline 6 (b) & Kaduna & $\begin{array}{l}\text { Ahmadu Bello } \\
\text { University Teaching } \\
\text { Hospital, Zaria }\end{array}$ & $\begin{array}{l}\text { June 2000-May } \\
2010\end{array}$ & 1 & nil & 1 & [23] \\
\hline 7 & Kano & $\begin{array}{lr}\text { Aminu } & \text { Kano } \\
\text { Teaching } & \text { Hospital, } \\
\text { Kano } & \end{array}$ & $\begin{array}{l}\text { January } 1996- \\
\text { December } 2005\end{array}$ & 5 & nil & 5 & [20] \\
\hline 8 (a) & Kwara State & $\begin{array}{l}\text { University of llorin } \\
\text { Teaching Hospital, } \\
\text { llorin }\end{array}$ & $\begin{array}{l}\text { January } 2002- \\
\text { December } 2008\end{array}$ & 17 & nil & 17 & [64] \\
\hline 8 (b) & Ogun & $\begin{array}{lr}\text { veterinary } & \text { and } \\
\text { human } & \text { hospitals } \\
\text { across all } & \text { zones in } \\
\text { the state } & \end{array}$ & 1997-2007 & 12 & nil & 12 & [65] \\
\hline 9 & Plateau & $\begin{array}{lr}\text { Jos } & \text { University } \\
\text { Teaching } & \text { Hospital, } \\
\text { the ECWA specialist } \\
\text { and Our Lady of } \\
\text { Apostle Hospital, Jos }\end{array}$ & 1998-2007 & 5 & nil & 5 & [34] \\
\hline \multirow[t]{2}{*}{10} & Sokoto & $\begin{array}{l}\text { Hospital and } \\
\text { veterinary centers in } \\
\text { Sokoto }\end{array}$ & 1980-1998 & 11 & nil & 11 & [66] \\
\hline & Total & & & 78 & & 78 & \\
\hline
\end{tabular}

Table 1: Actual records of human death recorded in health care institution in various states in Nigeria spanning from 1980 to 2014.

\section{Conclusion and Recommendation}

Rabies is endemic in Nigeria and rabies viral antigen has been detected in the brain tissues of apparently healthy dogs slaughtered for human consumption in almost all geopolitical zones of the country and poses a significant public health risk to dog meat processors and handlers. There have been published articles on deaths in humans due to rabies infection in some health care facilities across the country even though there are gross under-reporting of such deaths in the country. Dog bite cases are on the increase and are the main source of infection to humans.

There is need for a national rabies control programme that will be planned and executed jointly by both Veterinarians and human health workers, this programme should be supported and funded appropriately by relevant government agencies to ensure its success. Also private sector, non-governmental organizations, donor agencies should be mobilized by concerned health care authorities to invest in dog rabies prevention and control and also provide necessary logistics and funding. There is need for mass anti-rabies vaccination campaigns and public awareness programmes across the country on a regular basis in-order to control the disease among dog-population and educate dog owners on responsible dog ownership. This should involve both the mass media and relevant health care authorities. Veterinarians and human public health professionals should employ a one-world one-health approach in tackling this disease. Dog slaughtering points and dog markets across the country needs to be identified and dog meat processors and handlers should be educated on the need to be vaccinated yearly against rabies, and these vaccines should be made affordable and easily accessible. Standard reference rabies diagnosis laboratory should be constructed in all geopolitical zones to make diagnosis of animal and human rabies very easy. Also there is need to ensure strict leash laws to prevent straying of dogs. There should be establishment of modern veterinary clinics across the city to complement the existing ones in order to ensure that dog owners get access to veterinary services and where dog bite victims can readily obtained medical advice promptly.

There is also a need for collaborative effort by governments of neighbouring African countries such as Benin, Chad, Niger and Cameroon to ensure that movement of dogs across borders are controlled and the activities of middle men involved in this business are put to a halt to ensure control programme against rabies in each of these countries are not compromised. 


\section{References}

1. Dzikwi AA, Garkida AD, Umoh JU (2011) World Rabies Day: Efforts Towards Rabies Awareness in Zaria, Nigeria. Nigerian Veterinary Journal 32: 133-136.

2. Ehimiyein AM, Niezgoda M, Orciari L, Kuzmin I, Osinubi MOV, et al (2010) Rabies cases in dog markets in Kaduna State, northern Nigeria. International Journal of Infectious Diseases 14: e476.

3. Lembo T, Hampson K, Kaare MT, Ernest E, Knobel D, et al. (2010) The Feasibility of Canine Rabies Elimination in Africa: Dispelling Doubts. PloS Negleted Tropical Disease 4: 626

4. McKenzie AA (1993) Biology of the black jackal Canis mesomelas with reference to rabies. Onderstepoort Journal of Veterinary Research 60: 367-371.

5. Oginni FO, Akinwande JA, Fagade GF, Arole GF, Odunsanya SA (2002) Facial dog bites in South-Western Nigeria children: an analysis of eight cases. Tropical Doctor 32: 239- 240.

6. OIE (2012) Compedium of the OIE Global Conference on rabies control 7-9 September 2011 Incheon-Seoul (Republic of Korea). Rabies controltowards sustainable Prevention at the source.

7. Adeyemi IG, Zessin K (2000) Retrospective dog rabies vaccination evaluation at the University of Ibadan, Nigeria (1988-1992). Veterinarski Arhiv 70: 223-230.

8. Boulger LR, Hardy J (1960) Rabies in Nigeria. West Africa Medical Journal 9: 223-234

9. http://upetd.up.ac.za/thesis/available/etd-02252010-104653/unrestricted/ dissertation.pdf

10. Fagbami AH, Amosa VO, Ezebuiro EO (1981) Rabies in Nigeria American Journal of Tropical Medicine and Hygiene 75: 1.

11. Takayama N (2005) Clinical feature of human rabies. Nippon Rinsho 63: 2175-2179.

12. Center for Disease Control and Prevention (2011) Compendium of animal rabies prevention and control. Recommendations and reports. Morbidity and mortality weekly report 60: 1-14

13. www.cdc.gov/ncidod/dvrd/rabies/apps.who.int/iris/bitstream/ 10665/85346/1/ 9789240690943_eng. Pdf

14. Hemachudha T, Laothamatas J, Rupprecht CE (2002) Human rabies: a disease of complex neuropathogenetic mechanisms and diagnostic challenges. Lancet Neurol 1: 101-109.

15. Hemachudha $\mathrm{T}$ (2013) Human rabies: neuropathogenesis, diagnosis and management. Lancet Neurol 12: 498-513.

16. http://www.fao.org

17. Ojuawo A, Abdulkareem A (2000) Dog bite in children. Ilorin Sahel Medical Journal 3: 33-36

18. Istifanus AJ, Mohammed B, Samaila D (2012) Analysis of 4- year dogbite cases treated at the ahmadu bello university health centre, Zaria, Nigeria. TAF Prev Med Bull 11: 661-666.

19. Adeleke SI (2010) Impact Of Dog Bite In Kano City A Retrospective Study Nigerian. Journal of Clinical Practice 13: 67-69.

20. Aghahowa SE, Ogbeoveon RN (2010) Incidence of dog bite and antirabies vaccine utilization in the, University of Benin Teaching Hospital, Benin City, Nigeria: A 12-year assessment. Vaccine 28: 4847-4850.

21. Bata SI, Dzikwi AA, Ayika DG (2011) Retrospective study of dog bite cases reported to ECWA veterinary clinic, Bukuru, Plateau state, Nigeria. Science World Journal 6: 4.

22. Abubakar SA, Bakari AG (2012) Incidence of dog bite injuries and clinical rabies institution: A 10-year retrospective study annals of African medicine 11: 108-111.

23. Karshima NS, Kujul NB, Ogbu KI, Abdullateef MH, Dung PA, et al. (2013) Incidence and Risk Factors associated with Rabies and Dog Bites among Dogs Involved in Bites in Plateau State, Nigeria between 2011 and 2012. Journal on Animal Science Advances 3: 114-120.

24. Mshelbwala PP, Maikai VB, Angani MT, Nlebedum UC, Nwokocha QN et al. (2013) Retrospective study of dog bite cases reported to zona veterinary clinic, umuahia, abia state, Nigeria. Journal of Experimental Biology and Agricultural Sciences 1.

25. Atuman YJ, Ogunkoya AB, Adawa DAY, Nok AJ, Biallah MB (2014) Dog ecology, dog bites and rabies vaccination rates in Bauchi State, Nigeria. International Journal of Veterinary Science and Medicine 2: 41-45.

26. Hambolu SE, Dzikwi AA, Kwaga JKP, Kazeem HM, Umoh JU, et al. (2014) Rabies and Dog Bites Cases in Lagos State Nigeria: A Prevalence and Retrospective Studies (2006-2011). Global Journal of Health Science

27. Otolorin GR, Umoh JU, Dzikwi, AA (2014) Cases of dog bite in Aba Abia state Nigeria and its public health significance. International Journal of Tropical Disease and Health 4: 1097-1103.

28. Aiyedun JO, Olugasa BO (2012) Use of aerial photograph to enhance dog population census in Ilorin, Nigeria. Sokoto Journal of Veterinary Science 10: 22-27.

29. Otolorin GR, Umoh JU, Dzikwi AA (2014) Demographic and Ecological Survey of Dog Population in Aba, Abia State, Nigeria. ISRN Veterinary Sciene.

30. Hambolu SE, Dzikwi AA, Kwaga JKP, Kazeem HM, Umoh JU, et al. (2012) Dog Ecology and Population Studies in Lagos State, Nigeria Global Journal of Health Science 6.

31. Ajayi BB, Rabo JS, Baba SS (2006) Rabies in apparently healthy dogs histological and immunohistochemical studies. The Nigerian Postgraduate Medical Journal 12: 28-134.

32. Sabo G, Umoh JU, Sackey AKB, Ahmad A, Okolocha EC (2008) The role of dog trade in the epidemiology of rabies. Veterinary Clinical Practice Bulletin 1: 63-72.

33. Idachaba SE, Olaleye S, Chukwukere S, Abechi AS, Ehizobolo DO, et al. (2009) Ten year ( 1998- 2007) Retrospective evaluation of the status of dogs rabies in Plateau state, Nigeria. Proceedings of the 46th Annual Congress of the Nigeria Veterinary Medical Association 73-78.

34. Akombo PM (2009) Dog ecology and epidemiological studies of canine rabies in Benue State, Nigeria.

35. Aliyu TB, De N, Yenda EN, Lynn M (2010) Prevalence of rabies virus antigens in apparently healthy dogs in Yola, Nigeria. The Research 2 1553- 9865 .

36. Garba A, Oboegbulem SI, Junaidu AU, Magaji AA, Umoh JU, et al (2010) Rabies virus antigen in the brains of apparently healthy slaughtered dogs in Sokoto and Katsina States, Nigeria. Nigerian Journal of Parasitology 31: 123-125.

37. Odeh EL, Umoh JU, Dzikwi AA (2013) Assessement of risk of possible exposure to rabies among processors and consumers of dog meat in Zaria and Kafanchan, Kaduna state. Glob J Health Sci 6: 142.

38. Isek TI (2013) Epidemiological studies of canine rabies in Ogoja, Crossriver State, Nigeria (Unpublished Master's Thesis). Ahmadu Bello University, Nigeria.

39. Ekanem EE, Eyong KI, Philip-Ephraim EE, Eyong ME, Adams EB, et al (2013) Stray dog trade fuelled by dog meat consumption as a risk factor for rabies infection in Calabar, southern Nigeria. Afr Health Sci 13: 1170-1173.

40. Otolorin GR, Umoh JU, Dzikwi AA (2014) Prevalence of rabies antigen in brain tissue of dogs slaughtered for human consumption and evaluation of vaccination of dogs against rabies in Aba, Abia state Nigeria. World Journal of Public Health Sciences 3: 5.

41. Ameh VO, Dzikwi AA, Umoh JU (2014) Assessment of Knowledge, Attitude and Practice of dog owners to Rabies in Wukari Metropolis Taraba State, Nigeria. Glob J Health Sci 6: 226-240.

42. Mshelbwala PP, Ogunkoya AB, Maikai BV (2013) Detection of rabies antigen in the saliva and brains of apparently healthy dogs slaughtered for human consumption and its public health implications in Abia State, Nigeria. ISRN Veterinary Science.

43. Teulieres LN, Roumiantzeff A, Saliou MP (1988) Prevention of human rabies. Proceeding of the international conference on epidemiology, control, and prevention of rabies and brucellosis in Eastern and Southern African countries, Garborone. 81-93. 
Citation: Otolorin GR, Aiyedun JO, Mshelbwala PP, Ameh VO, Dzikwi AA, et al. (2015) A Review on Human Deaths Associated with Rabies in Nigeria. J Vaccines Vaccin 6: 262. doi:10.4172/2157-7560.1000262

Page 6 of 6

44. World Health Organization (1989) Guidelines for dog rabies control. World Health Organization. Geneva.

45. World Health Organization (2004) WHO Expert Consultation on Rabies: First report. WHO Technical Report Series 931. World Health Organization, Geneva, Switzerland.

46. http://www.oie.int/eng/A_RABIES/presentations.htm

47. Adeyemi IG, Adetunji VO, James VO, Alonge DO (2005) Ten-Year (1993-2002) Retrospective Evaluation of Vaccination of Dogs against Rabies at the University of Ibadan, Nigeria. African Journal of Biomedical Research 8: 71-77.

48. Ogunkoya AB, Audu SW, Osinubi MOV (2012) Two fatal cases of Rabies as a result of bites from apparently healthy dogs. Proceedings of the World Rabies International, Global Alliance for Rabies Control WEBINAR

49. WHO (2010) Position paper on rabies vaccines. Weekly Epidemiological Record 85: 309-320.

50. Khokhar A, Meena GS, Malti M (2003) Profile of dog bite cases attending m.c.d. dispensary at Alipur, Delhi 2003. Indian Journal of Community Medicine 4: 157-160.

51. Knopf L, Kim YJ, Erlacher-Vindel (2012) World Organisation for animal health standards and scientific activities for rabies control.

52. Bruckner (2012) Mainstreaming rabies prevention and control at the national level: A focus on the role of national Veterinary Services.

53. Ehimiyein A, Audu S, Ehimiyein I (2014) The Role Of Dog Trading And Slaughter For Meat In Rabies Epidemiology With Special Reference To Nigeria- A Review. 2.

54. Ehimiyein AM, Ehimiyein IO (2014) Rabies-Its Previous And Current Trend As An Endemic Disease Of Humans And Mammals In Nigeria. Journal of Experimental Biology and Agricultural Sciences 2.

55. http://rabiesalliance.org/favicon.ico
56. Garba A, Dzikwi AA, Okewole PA, Chitunya-Wilson BB, Tirmidhi AB, et al. (2013) Evaluation of dog slaughter and consumption practices related to the control of rabies in Nigeria. Journal of Experimental Biology and Agricultural Sciences 1.

57. Elisha IL, Solomon P (2008) Cruelty to dogs: A survey of responses in Bukuru Metropolis, Jos- Nigeria. Nigerian Veterinary Journal 29: 63-67.

58. Baba UA, Zwabragi J (2012) Case Report: Dilemma in managing human clinical rabies encephalitis in a developing country: a case report of a twelve year old girl from Paediatric department of a health facility in Yola, Adamawa state, North-Eastern Nigeria. Global Advanced Research Journal of Microbiology 1: 160-162.

59. Bello M, Lukshi BM, Usman B (2007) A fifteen-year retrospective study of the prevalence of rabies in Bauchi state, Nigeria. Nigerian Veterinary Journal 28: 18-23.

60. Osaghae DO (2011) Animal and human bites in children. West Afr J Med 30: 421-424.

61. Olarinde OJ, Olatunji OY (2014) Pattern of deaths in medical wards of a rurally situated tertiary health institution, Ido-Ekiti, Nigeria. Niger J Clin Pract 17: 237-240.

62. Dzikwi AA, Abbas II (2012) Mapping the Spatial Distribution of Rabies in Kaduna State, Nigeria (1999-2009) Using Geographic Information Systems Technology. Environment and Natural Resources Research 2.

63. www.varfbulletin.com

64. Kehinde OO, Adebowale OO, Olaogun MO, Olukunle, Adebowale O (2009) Situation Of Rabies In A Southwestern State of Nigeria: A Retrospective Study (1997-2007). J Agric Sci Env 9: 93-99.

65. Ahmed H, Chafe UM, Magaji AA, Abdul-Qadir A (2000) Rabies and dog bite in children: a decade of experience in Sokoto, Nigeria. Sokoto Journal of Veterinary Sciences 2: 2-10. 